\title{
KONG KAI BERTANGGA NADA SELENDRO: KAJIAN ORGANOLOGI KONG KAI PADA MASYARAKAT HELONG DI PULAU SEMAU
}

\author{
Relin Yosi Huka \\ Afiliasi: Institut Agama Kristen Negeri Kupang \\ relin_art@yahoo.com
}

\begin{abstract}
The purpose of this study was to examine the structure of Kong Kai's music in the Helong community on Semau Island. This research focuses on Kong Kai sounds that have not been made in a particular musical scale. Kong Kai has a different sound than the others. The author intends to establish a standard for the uniform sound settings in all of Semau Island. The author intends to explore how to make and play kong kai. The research method used is descriptive qualitative. With the interview and observation approach, the writer seeks information about Kong Kai. Alat musik Kong Kai can be measured with conventional western musical scales. Kong Kai has the same musical scales as Slendro.
\end{abstract}

Keywords: kong kai, alat musik, musical scale

\begin{abstract}
Abstrak
Tujuan dari penelitian ini adalah untuk mengkaji struktur musik Kong Kai pada masyarakat Helong di pulau Semau. Penelitian ini berpusat pada bunyi kong kai yang belum dibuat dalam tangga nada tertentu. Kong kai mempunyai bunyi yang berbeda dari yang lainnya. Penulis bermaksud membuat standarisasi pitch kong kai di seluruh Pulau Semau. Penulis bermaksud menelusuri cara membuat dan memainkan kong kai. Metode penelitian yang digunakan adalah deskriptif kualitatif. Dengan pendekatan wawancara dan observasi, penulis mencari informasi mengenai kong kai. Alat musik Kong kai dapat diukur dengan tangga nada konvensional barat. Kong kai memiliki tangga nada yang sama dengan slendro.
\end{abstract}

Kata Kunci: kong kai, alat musik, tangga nada 


\section{Pendahuluan}

Indonesia merupakan negara kepulauan yang memiliki berbagai macam musik serta etnik yang beragam dan tersebar di berbagai daerah (dengan sebaran sosiogeorafis yang luas). Dalam keberagaman musik di Indonesia juga terdapat berbagai macam alat yang dipakai untuk pementasan musik. Musik merupakan sekumpulan nada yang mengandung ritme, melodi, harmoni serta merupakan satu pernyataan ide musikal tertentu. Musik menyangkut sebuah ungkapan perasaan yang timbul dari diri seseorang kemudian ditransformasi menjadi sebuah karya. Indonesia juga memiliki beraneka ragam etnik budaya dari setiap daerah, diantaranya yaitu: rumah adat, pakaian adat, tarian adat, dan alat musik tradisional. Berbicara mengenai keanekaragaman etnik serta alat musik tradisional di Indonesia masing-masing memiliki keunikannya tersendiri.

Defenisi musik menurut Kamus Musik mengatakan bahwa seni pengungkapan gagasan melalui bunyi, yang unsur dasarnya berupa melodi, irama, dan harmoni, dengan unsur pendukung berupa bentuk gagasan, sifat, dan warna bunyi. Namun dalam penyajiannya sering musik dipadu dengan unsur-unsur lain seperti bahasa, gerak, ataupun warna. ${ }^{1}$ Sedangkan Kamus Besar Bahasa Indonesia menjelaskan, musik adalah ilmu atau seni menyusun nada atau suara dalam urutan, kombinasi, dan hubungan temporal untuk menghasilkan komposisi (suara) yang mempunyai kesatuan dan kesinambungan. ${ }^{2}$ Musik juga merupakan nada atau suara yang disusun sedemikian rupa sehingga mengandung irama, lagu, dan keharmonisan (terutama yang menggunakan alat-alat yang dapat menghasilkan bunyi-bunyi).

Salah satu teknik permainan musik tradisional yang diteliti oleh Herman ialah pakacaping. Pakacaping merupakan seni pertunjukan yang terdapat dalam masyarakat di setiap etnis yang ada di provinsi Sulawesi Selatan. Pakacaping dari tiap etnis dapat ditemui dari segi musikalitasnya pada saat membawakan sebuah lagu dan pengungkapan syair dan organologi serta teknik permainan yang memiliki keunikan dan kekhasan masing-masing. Bentuk instrumen kacaping menyerupai perahu, dan tidak memiliki standarisasi mengenai ukuran instrumen, (c) bagian-bagian instrumen Kacaping yaitu Toli (tuning pegs), Pasanggana (nut), Gigi (grip), Kalenna (badan), Leko' (daun: bagian paling ujung atas instrumen Kacaping), Pocci'na (lubang resonansi), Gallang (senar), kedong (ekor), (d) instrumen Kacaping memiliki tujuh nada. ${ }^{3}$ Lina Herlinawati meneliti mengenai Karinding bagi masyarakat Cikalongkulon kabupaten Cianjur. Alat karinding yang bisa digunakan untuk bermain musik pun kemudian berkembang menjadi alat musik tradisional Sunda yang mengagumkan. Karinding termasuk alat musik sejenis harpa rahang. Cara menggunakannya, selain ditiup, ujung karinding dipukul dengan telunjuk hingga menghasilkan bunyi. Alat ini ditempatkan di mulut sebagai resonansinya, dan lidah sebagai pengontrol bunyi yang diinginkan. ${ }^{4}$

Alat musik tradisional di berbagai daerah di Nusa Tenggara Timur (NTT) memiliki keunikan tersendiri. Alat musik tradisional memiliki banyak fungsi misalnya biasa digunakan dalam berbagai acara adat, pernikahan, penyambutan tamu, dan lain sebagainya. Beberapa Alat musik NTT yang sangat terkenal di kalangan masyarakat di antaranya adalah Sasando, Gong, Heo, Leku Boko, Foy Doa, Foy Pay, Suling dan lain sebagainya.

\footnotetext{
${ }^{1}$ M. Soeharto, Kamus Musik (Jakarta: PT Gramedia Widiasarana Indonesia, 1992), 86.

${ }^{2}$ Kamus Besar Bahasa Indoanesia, Edisi Keempat (Jakarta: Gramedia Pustaka Utama, 2008), $942-$ 943.

${ }^{3}$ Herman, “Organologi Dan Teknik Permainan Musik Pakacaping Etnis Makassar Kabupaten Gowa Propinsi Sulawesi Selatan," 2012.

4Lina Herlinawati, "Fungsi Karinding Bagi Masyarakat Cikalongkulon Kabupaten Cianjur," Patanjala: Jurnal Penelitian Sejarah dan Budaya 1 (2009): 96.
} 
Alat musik tradisional dari masing-masing daerah sangatlah penting bagi kehidupan masyarakat sebab kehidupan masyarakat tidak akan terlepas dari adat istiadat pada masyarakat di daerah itu. Kebudayaan harus tetap dijaga dan dilestarikan ciri khas daerah serta fungsi dari alat musik tradisional tersebut. Namun karena faktor perkembangan zaman dan modernisasi sangat memengaruhi keberlangsungan identitas suatu daerah. Maka identitas budaya dari suatu daerah sangat dipengaruhi, hal ini berdampak pada pelestarian alat musik tradisional pada masyarakat semakin minim pengetahuannya seperti pengenalan akan alat musik tradisional pada suatu daerah terhadap generasi-generasi yang akan datang dan atau kehilangan alat musik tradisional yang sudah ditinggalkan oleh leluhur dari sejak dulu. Salah satu daerah di NTT yang sudah terancam kekhasan alat musik tradisionalnya adalah Pulau Semau, tepatnya di Kampung Lenitian, Uing Bilat, Kecamatan Semau Selatan, Kabupaten Kupang.

Masyarakat Helong Semau merupakan salah satu kelompok yang memelihara alat musik tradisional. Alat musik tersebut dikenal dengan gong kayu. Dalam bahasa daerah Helong Semau gong kayu biasanya disebut kong kai. Kong Kai dibuat dari bilah-bilah kayu balok berbentuk persegi panjang dengan ukuran berbeda-beda. Unsur nada yang dihasilkan dapat diketahui dari unsur ketebalan bilah kayu tersebut sehingga dapat membedakan antara nada rendah dan nada tinggi. Adapun alat musik yang lainnya yang serupa dengan kong kai pulau Semau yaitu alat musik Kolintang dan alat musik Gambang. Kolintang adalah Alat musik sejenis gambang atau silofon khususnya dari daerah Sulawesi Utara. Tiap satuan alat memakai 14 sampai 21 bilah-bilah kayu, dengan panjang masing-masing antara 30 sampai $100 \mathrm{~cm}$, yang disusun berjajar di atas sebuah kotak resonator dari kayu pula.

Dari sisi bunyi, Kong kai belum bisa dipetakan dalam tangga nada tertentu dikarenakan Kong kai memiliki beberapa bentuk setingan bunyi yang pada dasarnya memiliki karakter bunyi yang berbeda. Di Kampung Lenitian, Uing Bilat, struktur tangga nada Kong kai berbeda dengan desa-desa lainnya, hal ini diakibatkan tidak ada standar penyeragaman setingan untuk keseluruhan alat tersebut. Berdasarkan masalah yang dipaparkan di atas, maka penulis mengkaji struktur musikal wadira Kong Kai pada masyarakat Helong di Pulau Semau.

\section{Metode Penelitian}

Metode yang digunakan dalam penelitian ini adalah metode deskriptif kualitatif. Penelitian deskriptif kualitatif berusaha mendeskripsikan seluruh gejala atau keadaan yang ada, yaitu keadaan masalah menurut apa adanya pada saat penelitian dilakukan. ${ }^{5}$ Metode penelitian kualitatif merupakan penelitian yang bersifat deskripsi, cenderung menggunakan analisis dan lebih menonjolkan proses makna. ${ }^{6}$ Menurut Merriam yang dikutip oleh John W. Cresswell salah satau bagian yang dilakukan peneliti adalah secara langsung menghubungi beberapa orang, latar belakang, lokasi untuk mengamati atau mencatat perilaku. ${ }^{7}$ Maka langkah penelitian yang dilakukan penulis yakni pertama, mempelajari penemuan riset bagi produk yang dikembangkan dengan melakukan riset kecil-kecilan. Kedua, mengembangkan produk berdasarkan penemuan riset. Produk diujicobakan dilapangan sesuai bentuk awal. Ketiga, melakukan uji lapangan terhadap produk. Keempat, memperbaiki produk dengan membetulkan kekurangan yang dijumpai

${ }^{5}$ Mukhtar, Metode Praktis Penelitian Deskriptif Kualitatif (Jakarta: Referensi, 2013), 28.

${ }^{6}$ Yolanda Kadjakoro, "Konsep Prajurit Allah Berdasarkan Efesus 6:10-20 Dan Implementasinya Dalam Kehidupan Orang Percaya," Jurnal Ilmiah Religiosity Entity Humanity (JIREH) 1, no. 1 (2019): 40-56, https://ojs-jireh.org/index.php/jireh/article/view/6.

${ }^{7}$ Hamid Patilima, Metode Penelitian Kualitatif (Bandung: Alfabeta, 2013), 60. 
pada saat tahap uji coba lapangan terhadapalat musik tradisional Kong Kai di masyarakat Kampung Lenitian, Uing Bilat, Kecamatan Semau Selatan, Kabupaten Kupang. ${ }^{8}$

\section{Hasil dan Pembahasan}

\section{Organologi Alat Musik Kong Kai}

Alat musik kong kai merupakan salah satu bentuk alat musik tradisional Pulau Semau. Permainan Alat musik kong kai ini dengan cara dipukul. Berdasarkan hasil wawancara, tahun 1947 mulai masuknya penginjilan di Pulau Semau, saat itu dipakai acara penyambutan untuk menerima masuknya injil tersebut. Namun dalam acara adat tersebut di Semau belum ada alat musik gong yang ingin dipakai dalam acara penyambutan tersebut. Oleh karena itu, seorang yang berasal dari Rote yang tinggal di Semau (yang sampai saat ini namanya belum diketahui tapi marga orang tersebut adalah Manafe). Dikisahkan selanjutnya Manafe meminta kesempatan untuk pergi ke Rote dan mengambil gong kayu tersebut dan ia kembali ke Pulau Semau membawa gong kayu tersebut. Sehingga dalam acara penyambutan masuknya injil diiringi dengan gong kayu yang dibawa oleh Manafe. Dari situlah masyarakat Helong Pulau Semau menjadikan alat musik gong kayu itu sebagai alat musik asli suku Helong Semau. Karena dilihat dari bentuk dan cara pembuatan yang mudah (khusus orang Helong Semau) sehingga sudah menjadi alat musik asli Pulau Semau sampai saat ini.

Alat musik kong kai ini tergolong dalam jenis alat musik idiophone yang sumber bunyinya berasal dari alat musik itu sendiri. Kong kai berjumlah 9 bilah kayu dan 4 batang alat pemukul (alat untuk memainkan gong) yang terbuat dari kayu pula, dengan ukuran panjang $20 \mathrm{~cm}$ dan lingkaran kayu berukuran $6 \mathrm{~cm}$. Dari ke-9 (sembilan) gong atau bilah kayu tersebut disusun sejajar dengan jarak antara gong yang satu ke gong yang lain berukuran $5 \mathrm{~cm}$, kemudian penyusunannya disesuikan dengan peraturan susunan nadanya, yang dimana akan diletakan pada suatu tempat (meja) berbentuk rangka yang terbuat dari kayu pula. Tinggi meja tempat meletakan gong berukuran 1 meter, sedangkan lebarnya 35 cm dan panjangnya 2 meter (rancangan RL). ${ }^{9}$ Gambar di bawah ini adalah contoh gambar kong kai.

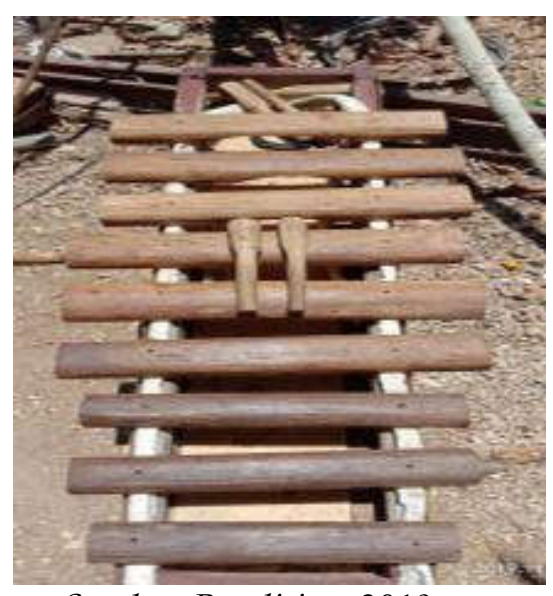

Sumber: Penelitian, 2019

Gambar 1. Tempat gong, susunan gong, dan alat pemukul

${ }^{8}$ Andreas B. Subagyo, Pengantar Riset Kuantitatif Dan Kualitatif Termasuk Riset Teologi Dan Keagamaan (Bandung: Kalam Hidup, 2014), 105.

9Wawancara dengan Informan Pembuat Kong Kai (Sabtu 23 November, Pukul 18.00.), (Kampung Lenitian, Uing Bilat, 2019). 


\section{Bentuk Kong Kai}

Berdasarkan hasil penelitian, peneliti mengamati secara langsung bahwa alat musik kong kai berbentuk balok dengan ukuran yang berbeda-beda baik itu dari panjang, lebar dan ketebalan dari setiap balok (bilahan) kayu tersebut. Peneliti melakukan pengukuran dari setiap gong sehingga mendapatkan hasil yang sudah diketahui. ${ }^{10}$ Peneliti menelusuri setiap bilah kayu, sehingga rata-rata dari setiap gong memiliki ukuran panjangnya kurang lebih 35 cm sampai dengan $45 \mathrm{~cm}$, lebar kurang lebih $6 \mathrm{~cm}$ sampai dengan $9 \mathrm{~cm}$, sedangkan ketebalan kurang lebih $3 \mathrm{~cm}$ sampai $4,5 \mathrm{~cm}$. Bentuk kong kai ini sebagaimana yang dibuat oleh RL (pembuat) gong ini sangat bermanfaat untuk para pemain gong, karena sangat mempermudah para pemain bergerak. Berbeda dengan pembuatan-pembuatan sebelumnya dimana dalam pembuatan mempunyai ukuran yang sedang, baik itu dari bentuk gongnya maupun dari tempat meletakan gong. Sehingga dalam permainannya harus dalam keadaan duduk sehingga bisa menyebabkan para pemain mengalami kecapaian. ${ }^{11}$ Contoh bentuk pengukuran bilah kayu (gong) seperti pada gambar berikut:

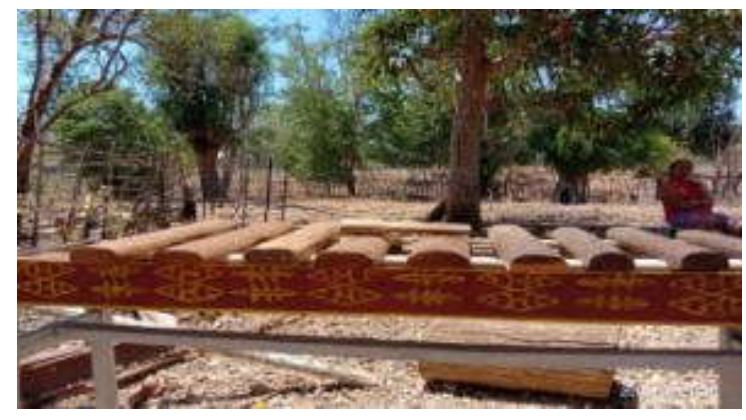

Sumber: Penelitian, 2019

Gambar 2. Kong Kai tampak dari samping

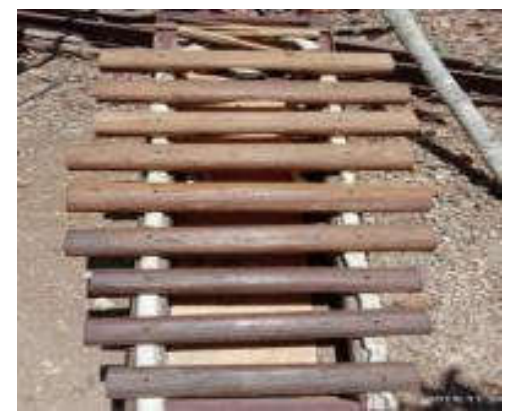

Sumber: Penelitian, 2019

Gambar 3. Kong Kai tampak dari atas

Peneliti mengamati ternyata tidak semua gong atau bilahan kayu berbentuk utuh. Akan tetapi, ada bilahan kayu yang mempunyai potongan berbentuk cekung pada bagian bawah tepatnya di tengah-tengah dari gong atau bilah kayu tersebut, dimana di bagian atas dari bentuk cekungan tersebut merupakan tempat jatuhnya pemukul yang menghasilkan bunyi dari gong itu sendiri. Setiap gong yang mempunyai potongan berbentuk cekung mempunyai ukuran lekukan yang berbeda-beda.

\footnotetext{
${ }^{10}$ Berdasarkan hasil wawancara dari informan RL warga Kampung Lenitian, Uing Bilat "sebagai pembuat kong kai" pada hari Jumat 23 November 2019, pukul 12.00 WITA.

${ }^{11 B e r d a s a r k a n}$ hasil wawancara informan RL "pembuat kong kai" pada Jumat 23 November 2019, pukul 12.00 WITA, di rumah informan RL.
} 
Fungsi pembuatan lekukan ini untuk memperoleh bunyi nada yang sedang dan rendah, dan bentuk lekukan ini hanya berlaku bagi gong II, III, karena bunyi yang dihasilkan sudah dikategorikan sebagai unsur bunyi nada yang sedang ke unsur bunyi nada yang paling rendah. Sedangkan pada gong I memiliki bentuk ukuran yang utuh karena bunyi dari Alat musik ini sudah termasuk dalam kategori nada paling tinggi, sehingga tidak perlu dibuat lekukan. ${ }^{12}$ Pembuatan lekungan pada gong II, III, memiliki bentuk ukuran lebar yang berbeda-beda tergantung nada yang diinginkan. Pada ukuran lebar lekungan ada yang $2 \mathrm{~cm}$ sampai $6 \mathrm{~cm}$. Berikut ini merupakan salah satu contoh gambar alat musik gong kayu yang memiliki lekungan sebagai berikut :

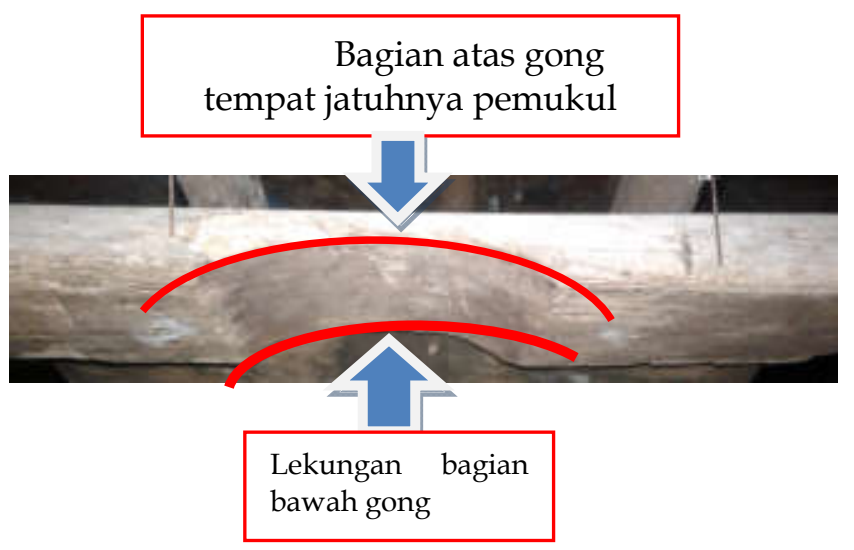

Gambar 4. Bentuk gong yang mempunyai lekukan

\section{Pembuatan Kong Kai}

Berdasarkan hasil wawancara diperoleh informasi bahwa ternyata tidak semua kayu bisa dipergunakan untuk membuat alat musik kong kai. Hanya ada 2 jenis pohon yang bisa digunakan sebagai bahan dasar dalam pembuatan kong kai,yaitu kai nala atau biasa dikenal dengan nama pohon "kayu merah" dan kai kla atau biasa disebut juga "kayu kula."13 Contoh seperti pada gambar berikut ini:
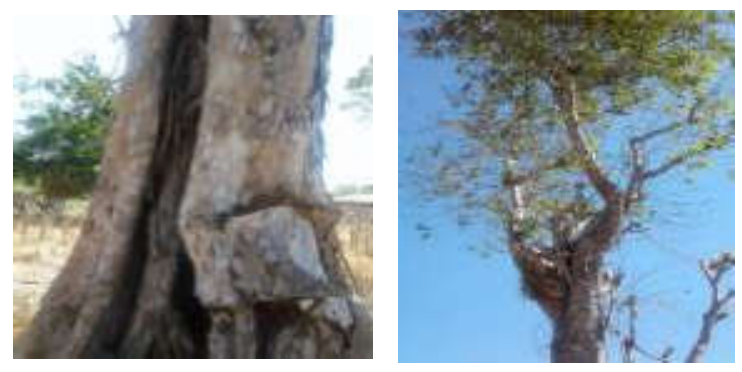

Gambar 5. Jenis Pohon Kai Nala (Kayu Merah)

\footnotetext{
${ }^{12}$ Berdasarkan hasil wawancara informan RL "sebagai pembuat kong kai" pada hari Sabtu 23 November 2019, pukul 18.00 WITA

${ }^{13}$ Berdasarkan hasil wawancara informan RL "sebagai pembuat kong kai" pada hari Sabtu 23 November 2019, pukul 18.00 WITA
} 


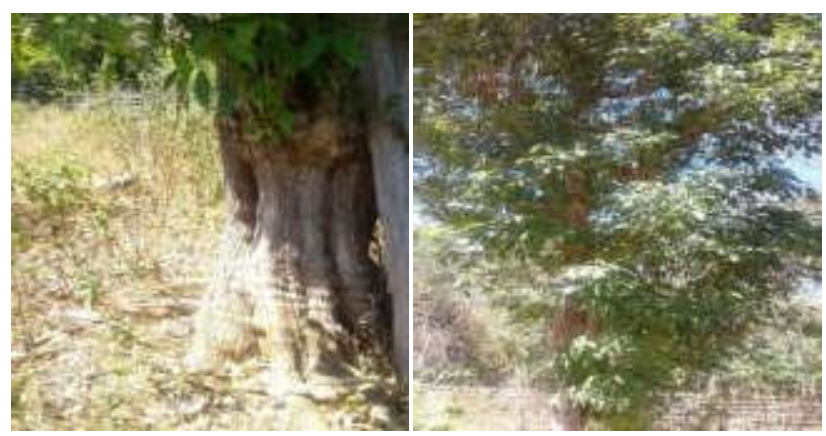

Gambar 6. Jenis Pohon Kai Kla (Kayu Kula)

Pengrajin kong kai mengatakan bahwa, hanya 2 jenis pohon ini yang bisa digunakan dalam pembuatan alat musik kong kai. Kedua jenis kayu ini dipilih karena dilihat dari sisi kualitas yang paling bagus, kuat, dan bertahan lama jika dirawat dengan baik. ${ }^{14}$ Bahkan bukan saja kuat dan bagus, namun dinilai dari sisi bunyi pun lebih baik kedengarannya dibanding dengan kayu-kayu lainnya yang sudah pernah dicoba oleh pengrajin. Akan tetapikayu-kayu lain tersebut kualitas dan bunyinya tidak semerdu dari kedua pohon pilihan tersebut bahkan lebih cepat rusak.

\section{Pemilihan Kayu}

Pemilihan pohon yang digunakan dalam pembuatan alat musik kong kai yaitu antara pohon kai nala (kayu merah) dan kai kla (kayu kula), seperti penjelasan sebelumnya bahwa hanya kedua jenis pohon inilah yang bisa dipakai dalam pembuatan alat musik kong kai. Kedua jenis pohon ini dari sisi kualitas merupakan kayu yang paling bagus, kuat, dan bertahan lama bahkan bunyinya pun lebih merdu jika dimainkan. Dalam pemilihan pohon, perlu memperhatikan umur pohon, yaitu berkisar puluhan tahun karena khasiat yang paling bagus untuk digunakan adalah bagian isi dalamnya (lapisan kedua). ${ }^{15}$ Dibanding dengan pohon-pohon lain yang kualitasnya kurang bagus bahkan lebih cepat rusak baik dari sisi bentuk dan bunyinya pun sangat berpengaruh. Berikut ini merupakan contoh pemilihan bagian kayu yang digunakan untuk pembuatan kong kai:

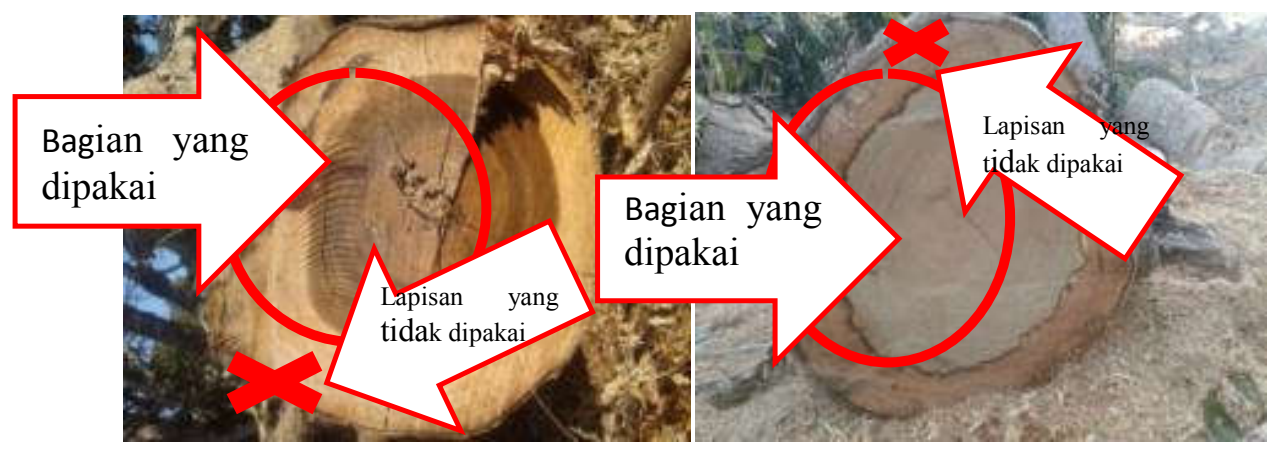

Gambar 7. Lapisan dalam Kayu Merah dan Kayu Kula

${ }^{14}$ Berdasarkan hasil wawancara informan RL "sebagai pembuat kong kai" pada hari Sabtu 23 November 2019, pukul 11.00 WITA.

${ }^{15}$ Berdasarkan hasil wawancara informan RL "sebagai pembuat kong kai" pada hari Sabtu 23 November 2019, pukul 11.00 WITA. 
Dalam proses pembuatan alat musik kong kai ini lebih cocok pada musim kemarau. Pemilihan waktu ini karena lebih tepat untuk proses pembuatannya, mulai dari tahap awal hingga selesai.

\section{Pemilahan dan Pengukuran}

Setelah melakukan penebangan, dilanjutkan dengan pemilahan (pisahkan) bagian isilapisan dalam (lapisan kedua) dipisahkan dari kulit luar dan lapisan luar (lapisan pertama). ${ }^{16}$ Dibelah (dipotong) berbentuk balok dengan panjang kurang lebih 1 meter, lebar kurang lebih $15 \mathrm{~cm}$, dan ketebalan rata-rata $6 \mathrm{~cm}$ untuk gong. Sedangkan untuk tempat meletakan gong memerlukan panjang kurang lebih 2,5 m, dengan lebar minimal $7 \mathrm{~cm}$, dan ketebalan minimal $5 \mathrm{~cm}$.

\section{Pengeringan}

Proses pengeringan dilakukan dengan menjemur potongan-potongan kayu yang sudah dibelah. Dalam proses pengeringan ini memerlukan waktu yang cukup lama tergantung cuaca. Karena jika cuaca cerah dengan terik matahari yang bagus, maka proses pengeringan lebih cepat. Proses pengeringan untuk kai nala (kayu merah) memerlukan waktu kurang lebih 1 (satu) Minggu, karena getah atau airnya tidak terlalu banyak (sedikit) sehingga lebih cepat proses pengeringannya. Sedangkan untuk kai kla (kayu kula) memerlukan waktu agak lebih lama darikayu merah. Waktu pengeringan kurang lebih 2 Minggu, karena getah atau airnya lebih banyak sehingga memerlukan waktu yang lebih banyak pula.

\section{Proses Pembersihan}

Bagian pembersihan ini dilakukan satu per satu dari setiap balok. Kemudian digergaji dan disekap (diperlicin) dari berbagai sisi balok. Pada bagian inisecara langsung dilanjutkan dengan tempat untuk meletakan gong. ${ }^{17}$ Pembuatan tempat ini dibuat sesui ukuran yang diinginkan tergantung selera. Sesui hasil penelitian yang peneliti amati, cara pembuatan menurut informan RL (pengrajin) memiliki ukuran panjang 2 meter, lebar $35 \mathrm{~cm}$, dan tinggi pasangan kaki 1 meter. Setelah selesai pembuatan tempat untuk meletakkan gong disertai pembuatan alat pemukul sebanyak 4 batang. Setelah itu dilanjutkan dengan sesi pemilahan nada.

\section{Finishing}

Pada tahapan ini perlu melakukan pemeliharaan terhadap alat musik kong kai, agar tidak mudah rusak. Sehingga kedepan alat musik ini bisa digunakan kapan saja bagi generasi-generasi penerus. Alat musik ini juga tetap dikenal sebagai alat musik tradisional asli suku Helong Semau. Karena jika tidak ada pemeliharaan pada alat musik ini, maka akan mudah rusak, bahkan bisa saja terhilang dari generasi-generasi mendatang. Oleh karena itu, hal ini harus benar-benar dijaga dan dipelajari karena sangat berguna dan bermanfaat bagi generasi-generasi penerus suku Helong Pulau Semau.

\section{Sistim Penalaan}

Dalam proses penalaan, hal yang paling utama adalah upaya mendengar dengan baik sehingga dapat menyusun dan menentukan tinggi rendah nada sesuai dengan

16 Berdasarkan hasil wawancara informan RL sebagai pembuat kong kaipada hari Sabtu 23 November 2019, pukul 11.00 WITA.

17Berdasarkan hasil wawancara informan RL "sebagai pembuat kong kai" pada hari Sabtu 23 November 2019, pukul 18.00 WITA. 
keinginan. Proses penalaan kong kai dilakukan dengan lebih dulu menentukan nada tertinggi dari setiap susunan kemudian diikuti oleh nada-nada yang di bawahnya. Sesuai dengan hasil wawancara, kong kai dibuat tidak berdasarkan sumber penalaan yang standar (piano, garputala, ataupun steamflute), atau jenis tuner yang lainnya tetapi dilakukan hanya berdasarkan perkiraan sang pembuat.

\section{Teori Akustika Organologi}

Dalam buku Organologi Akustika I dan II bahwa, organologi pada hakekatnya adalah mempelajari pengetahuan tentang alat-alat musik, baik dilihat dari segi bentuk, suara, cara memainkan, dan konteksnya dalam kehidupan manusia tentang alat musik tersebut serta bagaimana fungsi dari alat musik itu sendiri. Curt Sach dan Hornbaostel dalam buku Sri Hendarto mengklasifikasikan alat musik berdasarkan pada bahan yang menyebabkan timbulnya suara dalam 4 golongan, yaitu: pertama, idiophones yaitu bahan sumber bunyi pada semacam kayu, logam dan lain sebagainya baik yang keras maupun yang elastis yang dapat berbunyi tanpa bantuan membrane. Contohnya seperti gong, kolintang, angklung, dan simbal. Kedua, membraphone yaitu sumber bunyi yang berupa selaput yang dibentang. Contohnya sperti gendang, rebana, tifa, dan tambur. Ketiga, chordophones yaitu sumber bunyi dari sejenis tali, kawat, serat, dan sebagainya yang dibentangkan sehingga dapat menghasilkan suatu bunyi. Contohnya seperti sasando, biola, gitar, okulele, dan heo. Keempat, electrophone yaitualat musik yang ragam bunyinya dibantu adanya daya listrik. Contohnya seperti gitar listrik, bass elektrik, keyboard dan drumelektrik. ${ }^{18}$

Berdasarkan teori akustika organologi yang telah dijelaskan di atas, maka penulis akan mengkaji aspek struktural alat musikkong kai yang dikategorikan sebagai alat musik idiophones. Idiophone dibagi menjadi dua jenis kelompok ricikan, yaitu ricikan bilah dan ricikan pencon. Dua ricikan tersebut umumnya terbuat dari logam (perunggu, kuningan, atau besi). Kelompok ricikan bilah antara lain gender barung, gender penerus, slenthem, demung, saron, saron penerus, dan gambang (terbuat dari kayu). ${ }^{19}$ Kayu merupakan bagian dari idiophone karena sumber bunyinya berasal dari bahan kayu yang keras. Dalam hal ini, penulis mempelajari tentang struktur alat musik berdasarkan sumber bunyi, cara memproduksi bunyi, dan sistem pelarasan yang disebut organologi. Organologi mempunyai maksud sebagai gambaran tentang bentuk dan susunan, konstruksi suatu instrumen sehingga dapat menghasilkan suara seperti dalam konteks kong kai.

Organologi dalam istilah musik merupakan ilmu alat musik atau studi mengenai alat-alat musik. Organologi merupakan ilmu pengetahuan yang mempelajari tentang selukbeluk alat musik dari aspek fisik ataupun aspek nonfisiknya. Hal ini juga dikemukakan oleh Hendarto bahwa organologi merupakan satu cabang ilmu studi mempelajari instrumen atau alat musik baik dari aspek fisik maupun aspek nonfisiknya. Aspek fisik yang terdapat pada sebuah instrumen misalnya bahan, bentuk, konstruksi, cara pembuatan, penggolongan fisik, penalaran, dan lain sebagainya. Adapun aspek-aspek nonfisik yang terdapat pada sebuah instrumen misalnya fungsi pada musik, hubungannya dengan kedudukan musisi, sejarah, penyebaran, perbandingan, perkembangan teknik penyajian, dan lain sebagainya. Studi organologi ini dapat memberikan informasi tentang instrumen kong kai dari aspek fisik dan nonfisiknya. Jadi, paparan mengenai aspek fisik dan nonfisik yang dimaksud Hendarto dimulai dari bahan. ${ }^{20}$ Seh Kilang dan AE Mouse terinspirasi dari bebunyian yang berasal dari Gerantung yang digantung dileher kerbau itu, akhirnya mengubah notasi yang tidak

\footnotetext{
18Sri Hendarto; Sri Hastanto, Organologi Dan Akustika I \& II (Bandung: Lubuk Agung, 2011). 4

${ }^{19}$ Iwan Budi Santoso, "Ruang Pertunjukan Musik Karawitan(Gamelan Jawa)," Nuansa Journal of Arts and Design 1, no. 2 (2018): 80-93, accessed March 16, 2020.

${ }^{20}$ Hendarto, Organologi Dan Akustika I \& II. 2
} 
beraturan itu ke sebuah komposisi yang lebih teratur. Lama kelamaan hal tersebut menghasilkan sebuah Gerantung yang dipakai hingga kini. ${ }^{21}$ Bahan merupakan unsur utama karena bahan merupakan zat atau benda yang digunakan untuk membuat alat musik kong kai. Jadi perspektif organologis yang dipelajari, yaitu mencakup masalah bahan pembuatan, ukuran, teknik pembuatan, sistem tuning (menstem), dan lagu-lagu, serta sistem permainannya. ${ }^{22}$

\section{Fungsi Teori Akustik Organologi}

Akustik adalah ilmu suara dan berkaitan dengan asal suara baik dalam ruang kosong, atau di pipa dan saluran, atau tertutup/terisolasi. Frekuensi jangkauan pendengaran manusia sekitar $16 \mathrm{~Hz}$ sampai sekitar $20000 \mathrm{~Hz}$. Organologi mempelajari tentang struktur instrumen musik berdasarkan sumber bunyi, cara memproduksi bunyi dan sistem pelarasan. Organologi mempunyai maksud sebagai gambaran tentang bentuk dan rupa susunan pembagun konstruksi suatu gitar sehingga dapat menghasilkan suara seperti gitar kebanyakan. Organologi yaitu bentuk pengelompokan dan bagian-bagian dari instrumen musik yang ada yaitu: gerak, kekuatan dan energi, sistem vibrasi, gelombang mekanik dan gelombang bunyi, resonansi. ${ }^{23}$

Organologi dalam istilah musik merupakan ilmu alat musik, studi mengenai alat-alat musik. Alat musik adalah suatu instrumen yang dibuat atau dimodifikasi untuk tujuan menghasilkan musik. Pada prinsipnya, segala sesuatu yang memproduksi suara, dengan cara tertentu bisa diatur oleh musisi, dapat disebut dengan alat musik. Walaupun demikian, istilah ini umumnya diperuntukkan bagi alat yang khusus ditujukan untuk musik. Bidang ilmu yang mempelajari alat musik disebut organologi. Ilmu pengetahuan tentang organ dalam dunia musik adalah ilmu yang mempelajari tentang instrumen musik, klasifikasinya, bagian-bagiannya, dan fungsinya sehubungan dengan instrumen itu sendiri, dan budayanya.

\section{Struktur Musikal}

Secara umum alat musik gong memiliki nada, tapi alat musik kong kai dalam pembahasan ini fungsinya lebih banyak mengarah kepada alat musik ritmis. Hal ini terkait dengan fungsi alat musik ini sebagai pengiring dalam membentuk ritmis. Namun semua kong kai tersebut memiliki nada yang dapat ditentukan tonalnya. Pada dasarnya musik terdiri dari melodi, irama/pola ritme, harmoni horisontal maupun harmoni vertikal yang merupakan kesatuan yang membentuk suatu komposisi musik.

\section{Kong kai 1}

Berdasarkan hasil observasi, peneliti memperoleh data bahwa kong kai disusun dari nada tertinggi ke nada yang terendah. Hal ini dimaksudkan untuk memudahkan penentuan nada ke bawahnya dengan mempertimbangkan penyusunan ke atas atau ke arah nada tinggi akan sulit terjadi karena kayu untukpenentuan nada atas agak sedikit sulit didapatkan. ${ }^{24}$ Kong kai dalam kajian ini merupakan bagian yang tidak terpisahkan dari serangkaian gong kayu yang tersusun dalam satu susunan. Bagian ini terdiri atas dua bilah kayu yang

${ }^{21}$ Desi Munawarah, Instrumen Gerantung Pada Masyarakat Gayo Di Kabupaten Aceh Tengah (Kajian Organologi), 2017.

22Jufri, "Tinjauan Organologistalempong Batuang (Musik Bambu Minangkabau)," Wacana Etnik 3, no. 2 (2012): 183-209.

23Pita Silitonga, Akustik Organologi (Medan: Unimed Press, 2014), accessed March 16, 2020, https:/ /opac.perpusnas.go.id/DetailOpac.aspx?id=1061350\#.

${ }^{24}$ Berdasarkan hasil wawancara informan RL "sebagai pembuat kong kai" pada hari Sabtu 23 November 2019, pukul 12.00 WITA. 
memiliki bentuk panjang, lebar dan ketebalannya berbeda. Hal ini terkait dengan nada yang dihasilkan ternyata berbeda. Bagian ini dibuat dari kayu dengan panjang kurang lebih 45 $\mathrm{cm}$, lebar $7 \mathrm{~cm}$ dan tebalnya $5 \mathrm{~cm}$. Kong kai terdiri dari 2 bilah kayu dengan nada atasnya setelah diukur berada pada nada Es dengan susunan nada bawahnya adalah nada B. Rangkaian nada ini dimainkan secara berulang dengan pola ritme/iramanya selalu berulang. Setiap bagian dimainkan dengan formasi bunyi seperdelapan antara nada B dan Es. Jarak nada adalah terts besar. Bagian ini biasa dimainkan oleh seorang pemain yang memiliki kemampuan yang handal dalam mengatur tempo selain tempo yang akan diatur juga oleh pemain tambur.

Contoh ritme yang dihasilkan dari salah satu bentuk karya yang biasanya dipertunjukkan, sebagai berikut:

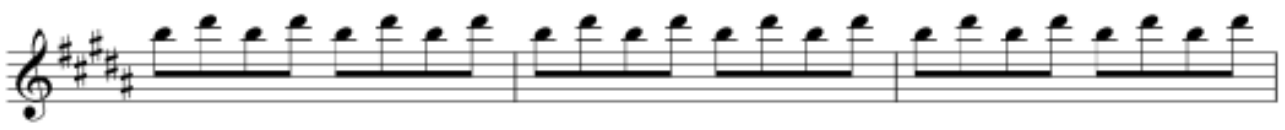

Notasi 1.1 bentuk ritmik Kong kai 1

Kong kai bagian ini sering terdengar cenderung membosankan karena irama/pola ritme tersebut selalu berulang dari awal sampai selesai sebuah karya dimainkan. Dari jarak nada yang sudah diketahui tersebut yakni jarak terts besar maka dapat diukur juga bahwa nada Es yang merupakan nada teratas tersebut menemiliki posisi pada Es2 dan nada berikutnya adalah nada B1. Berikut ini adalah interval atau jarak yang dapat dilihat dari notasi berikut ini:

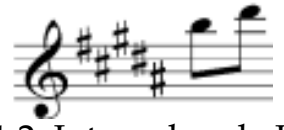

Notasi 1.2. Interval nada Kong kai 1

\section{Kong Kai 2}

Bagian kedua dari kong kai adalah 2 bilah kayu yang disusun dengan ukuran panjang kurang lebih $33 \mathrm{~cm}$, lebar $6 \mathrm{~cm}$ dan tebal $4 \mathrm{~cm}$. Bagian bilah kedua yaitu memiliki panjang $40 \mathrm{~cm}$ dan lebar $8 \mathrm{~cm}$ serta memiliki tebal $3,5 \mathrm{~cm}$. Bagian ini masih memiliki fungsi yang sama pada bagian kong kai 1 yaitu memainkan ritmik yang berulang-ulang dari awal sampai akhir. Menurut wawancara yang dilakukan ritmik yang dihasilkan terkadang menjadi ciri khas dalam menentukan asal dari sebuah karya pertunjukan. Setiap tempat memiliki ritmik khusus sebagai tanda bahwa dari mana karya yang dimainkan berasal.

Berikut ini adalah salah satu contoh itmik yang dihasilkan oleh permainan Kong kai 2:

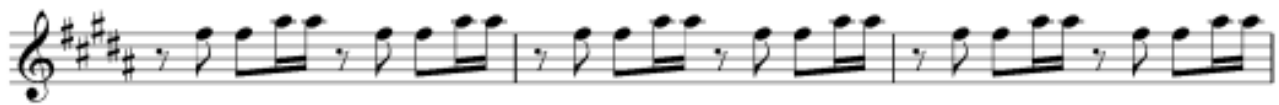

Notasi 1.3. Bentuk Ritmik Kong Kai 2

Dari penjelasan di atas dapat disimpulkan bahwa jarak nada yang ada pada kong kai 2 adalah sebagai berikut:

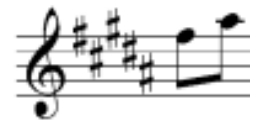

Notasi 1.4. Interval nada dari Kong Kai 2 


\section{Kong Kai 3}

Kong kai 3 terbentuk dari 5 bilah kayu, yang masing-masing kayu tersebut memiliki nada tersendiri. Nada pertama adalah nada E1, Eb1, B, Bb, dan Gb (disusun dari nada tertinggi). Bagian ini sering dimainkan sebagai ritmis maupun juga melodi. Bagian ini cenderung lebih kreatif dimainkan dibandingkan dengan kedua bagian yang sudah dibahas sebelumnya. Bagian ini dalam setiap proses permainannya langsung diambil alih permainannya oleh pembuat kong kai.

Bagian ke-3 ini sangatlah berperan penting di dalam setiap pertunjukan maupun pementasan karya-karya musik. Hal ini disebabkan karena bagian ini dalam setiap proses permainnya selalu menggabungkan 2 fungsi yaitu fungsi secara ritmis sekaligus juga fungsi secara melodis. Bilah kayu E1 memiliki panjang $40 \mathrm{~cm}$ dengan lebar $9 \mathrm{~cm}$ serta ketebalan 3,5 $\mathrm{cm}$. Setiap bagian terdapat bagian lengkungan di bagian bawahnya sebagai bentuk setingan (penyeteman nada). Bilah kayu berikutnya adalah Eb1 dengan panjang bilahan kayunya 39 $\mathrm{cm}$ dengan lebar $8 \mathrm{~cm}$ serta ketebalan $4 \mathrm{~cm}$. Masih tetap sama dengan bagian sebelumnya, bilahan bawahnya terdapat lengkungan sebagai tempat setingan.

Bagian berikut adalah bilahan kayu nada B dengan memiliki panjang $37 \mathrm{~cm}$ dan lebar $7 \mathrm{~cm}$, serta ketebalan $4 \mathrm{~cm}$. Bilahan kayu berikut adalah bilahan kayu dengan nada $\mathrm{Bb}$ dengan panjang $37 \mathrm{~cm}$ dan lebar $7 \mathrm{~cm}$, serta ketebalan $3 \mathrm{~cm}$. Bilahan kayu terakhir adalah dengan nada $\mathrm{Gb}$ dengan panjang $35 \mathrm{~cm}$, tebal $7 \mathrm{~cm}$, serta ketebalan $4 \mathrm{~cm}$. Setiap bilahan kayu tersebut masih memiliki bentuk yang hampir mirip di bagian bawahnya karena memiliki lengkungan tempat dilakukannya proses penyetelan nada. Dari kelima bagian tersebut dapat disusun bagian nadanya secara keseluruhan yang dapat dilihat pada notasi berikut ini:

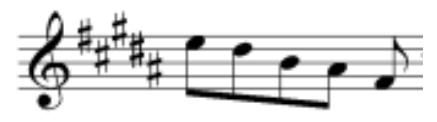

Notasi 1.5. Interval nada Kongkai 3

Kong kai 3 seringkali berfungsi sebagai pembawa melodi (kalupun ada lagu yang sesuai dengan nada kong kai 3), namun secara umum kong kai 3 difungsikan sebagai bagian variasi dari keseluruhan permainan kong kai. Dalam permainan bagian ini selalu memberikan nuansa-nuansa baru yang akan memberikan ciri kreatifitas pemainnya. Seorang pemain kong kai 3 lebih cenderung memiliki musikalitas yang tinggi. Dari uraian tentang interval nada kong kai 3, maka dapat digambarkan bentuk musik yang muncul dari permainan kong kai 3 sebagai berikut:

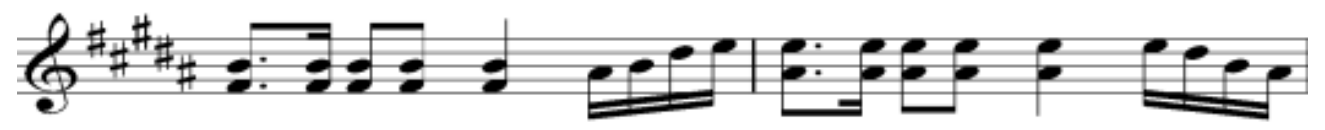

Notasi 1.6. Bentuk Musik Kongkai 3

Dari keseluruhan bilahan kayu di atas, dapat dirincikan ukurannya secara keseluruhan sebagai berikut:

Table No. 1.1 Ukuran bilahan kayu

\begin{tabular}{|l|c|l|l|l|l|}
\hline No & Urutan Bilah Kayu & Panjang & Lebar & Tebal & Nada \\
\hline 1. & Bilah 1 & $35 \mathrm{Cm}$ & $9 \mathrm{Cm}$ & $4 \mathrm{Cm}$ & Eb2 \\
\hline 2. & Bilah 2 & $37 \mathrm{Cm}$ & $8 \mathrm{Cm}$ & $4,5 \mathrm{Cm}$ & B1 \\
\hline 3. & Bilah 3 & $33 \mathrm{Cm}$ & $6 \mathrm{Cm}$ & $4 \mathrm{Cm}$ & Bb1 \\
\hline 4. & Bilah 4 & $40 \mathrm{Cm}$ & $8 \mathrm{Cm}$ & $3,5 \mathrm{Cm}$ & $\mathrm{Gb} 1$ \\
\hline
\end{tabular}




\begin{tabular}{|l|l|l|l|l|l|}
\hline 5. & Bilah 5 & $40 \mathrm{Cm}$ & $9 \mathrm{Cm}$ & $3,5 \mathrm{Cm}$ & E1 \\
\hline 6. & Bilah 6 & $39 \mathrm{Cm}$ & $8 \mathrm{Cm}$ & $4 \mathrm{Cm}$ & Eb1 \\
\hline 7. & Bilah 7 & $37 \mathrm{Cm}$ & $7 \mathrm{Cm}$ & $4 \mathrm{Cm}$ & B \\
\hline 8. & Bilah 8 & $37 \mathrm{Cm}$ & $7 \mathrm{Cm}$ & $3 \mathrm{Cm}$ & Bb \\
\hline 9. & Bilah 9 & $35 \mathrm{Cm}$ & $7 \mathrm{Cm}$ & $4 \mathrm{Cm}$ & $\mathrm{Gb}$ \\
\hline
\end{tabular}

Dari tabel di atas dapat disusun pola nada dari nada terendah sampai nada tertinggi atau sebaliknya seperti notasi berikut ini:

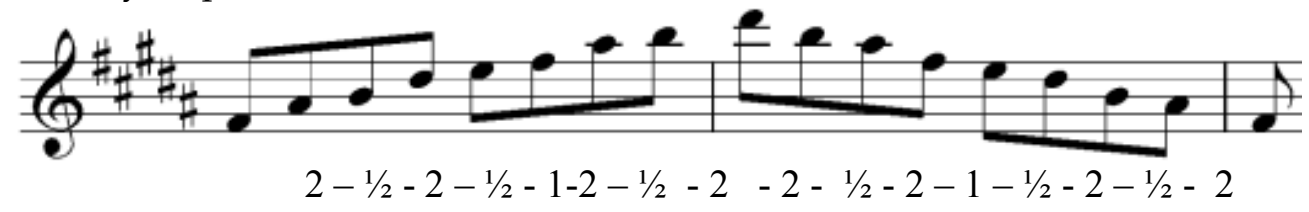

Notasi 1.7 Interval Keseluruhan Kong Kai

Dengan interval atau jarak nada:2 $-1 / 2-2-1 / 2-1-2-1 / 2-2$ dan turunnya $2-1 / 2-2-1-1 / 2-2-1 / 2-2$ yang dapat dijelaskan sebagai berikut:

Table 1.2. Interval nada dari kong kai

\begin{tabular}{|c|c|l|}
\hline Interval Nada & Jarak Nada & Nama Interval \\
\hline $\mathrm{Gb}-\mathrm{Bb}$ & 2 & Terts Besar \\
\hline $\mathrm{Bb}-\mathrm{B}$ & $1 / 2$ & Seconde Kecil \\
\hline $\mathrm{B}-\mathrm{Eb} 1$ & 2 & Terts Besar \\
\hline $\mathrm{Eb} 1-\mathrm{E} 1$ & $1 / 2$ & Seconde Kecil \\
\hline $\mathrm{E} 1-\mathrm{Gb} 1$ & 1 & Seconde \\
\hline $\mathrm{Gb} 1-\mathrm{Bb} 1$ & 2 & Terts Besar \\
\hline $\mathrm{Bb} 1-\mathrm{B} 1$ & $1 / 2$ & Seconde Kecil \\
\hline $\mathrm{B} 1-\mathrm{Eb} 2$ & 2 & Tert Besar \\
\hline & & \\
\hline
\end{tabular}

Susunan nada yang terbentuk tersebut, dapat dibuat sebuah kesimpulan bahwa struktur musikal atau tangga nada yang terbentuk dari kong kai adalah jenis pentatonik yang memiliki nada setengah. Jenis pentatonik ini biasanya dapat ditemukan dalam kekhasan lagu-lagu karawitan Jawa. Dalam hal ini dapat pula disimpulkan bahwa tangga nada ini hampir memiliki bentuk yang sama dengan tangga nada slendro.

\section{Rekomendasi untuk Penelitian Lanjutan}

Rekomendasi yang penulis sampaikan dalam penelitian ini merupakan pemikiran yang bukan hanya diperhatikan, akan tetapi sekiranya dilaksanakan oleh pihak-pihak yang berkompeten dalam melihat pengembangan musik tradisional di Nusa Tenggara Timur, terutama alat musikkong kai. Adapun rekomendasi penulis adalah: pertama, perlu dukungan moril, semangat, motivasi dan perhatian dari Pemerintah daerah untuk mengembangkan setiap potensi berkesenian yang ada untuk menjadi sebuah bentuk pelestarian budaya daerah. Kedua, kegiatan yang dilakukan untuk mengembangkan proses pembuatan alat musik kong kai agar lebih diperkenalkan lagi kepada masyarakat, lebih khusus kepada generasi muda sebagai bentuk pelestarian budaya daerah. Ketiga,perlu adanya pemahaman dari masyarakat sendiri terkait budaya dari tempat mereka berasal. 


\section{Kesimpulan}

Berdasarkan hasil penelitian, penulis menyimpulkan bahwa dari setiap alat musik ternyata memiliki tangga nada yang dapat diukur dengan menggunakan tangga nada konvensional Barat. Sehingga Penulis membuat standar penelaan kong kai setelah mengikuti piano, garputala, ataupun steamflute. Penulis menawarkan bunyi yang dikeluarkan oleh kong kai dalam tiga bagian seperti yang telah dipaparkan di atas. Hal yang perlu diperhatikan oleh pembuat kong kai dalam pembuatan tangga nada mengikuti jenis nada setengah. Tangga nada ini yang dibuat bisa mengikuti tangga nada slendro. Pembuatan melodi atau ritme dalam membentuk harmonisasi bunyi harus merupakan satu kesatuan dalam membentuk sebuah komposisi musik yang sesuai standar.

\section{Rujukan}

Banoe, Pono. Kamus Istilah Musik. Jakarta: CV. Baru, 1985.

Buy, Bernat; Robert Laiskodat. Wawancara Pembuat Kong Kai (Sabtu 23 November, Pukul 18.00.). Kampung Lenitian, Uing Bilat, 2019.

Hendarto, Sri; Sri Hastanto. Organologi Dan Akustika I \& II. Bandung: Lubuk Agung, 2011.

Herlinawati, Lina. "Fungsi Karinding Bagi Masyarakat Cikalongkulon Kabupaten Cianjur." Patanjala $\square$ : Jurnal Penelitian Sejarah dan Budaya 1 (2009): 96.

Herman. “Organologi Dan Teknik Permainan Musik Pakacaping Etnis Makassar Kabupaten Gowa Propinsi Sulawesi Selatan," 2012.

Jufri. “Tinjauan Organologistalempong Batuang (Musik Bambu Minangkabau)." Wacana Etnik 3, no. 2 (2012): 183-209.

Kadjakoro, Yolanda. "Konsep Prajurit Allah Berdasarkan Efesus 6:10-20 Dan Implementasinya Dalam Kehidupan Orang Percaya." Jurnal Ilmiah Religiosity Entity Humanity (JIREH) 1, no. 1 (2019): 40-56. https://ojsjireh.org/index.php/jireh/article/view/6.

Kamus Besar Bahasa Indonesia. Edisi Keempat. Jakarta: Gramedia Pustaka Utama, 2008.

Mukhtar. Metode Praktis Penelitian Deskriptif Kualitatif. Jakarta: Referensi, 2013.

Munawarah, Desi. Instrumen Gerantung Pada Masyarakat Gayo Di Kabupaten Aceh Tengah (Kajian Organologi), 2017.

Patilima, Hamid. Metode Penelitian Kualitatif. Bandung: Alfabeta, 2013.

Santoso, Iwan Budi. "Ruang Pertunjukan Musik Karawitan(Gamelan Jawa)." Nuansa Journal of Arts and Design 1, no. 2 (2018): 80-93. Accessed March 16, 2020.

Silitonga, Pita. Akustik Organologi . Medan: Unimed Press, 2014. Accessed March 16, 2020. https://opac.perpusnas.go.id/DetailOpac.aspx?id=1061350\#.

Soeharto, M. Kamus Musik. Jakarta: PT Gramedia Widiasarana Indonesia, 1992.

Subagyo, Andreas B. Pengantar Riset Kuantitatif Dan Kualitatif Termasuk Riset Teologi Dan Keagamaan. Bandung: Kalam Hidup, 2014. 